\title{
THE INFLUENCE OF MOTION GAMES IN THE IMPROVEMENT OF PSYCHOMOTRICITY DURING THE PHYSICAL EDUCATION LESSON IN PRIMARY SCHOOL EDUCATION
}

T.M. Iconomescu', ticonomescu@ugal.ro, ORCID: 0000-0001-5780-4403,

A. Berdilä', annie.volley@yahoo.com, ORCID: 0000-0003-2032-2667,

L.G. Talaghir ${ }^{1,2}$, gtalaghir@ugal.ro, ORCID: 0000-0002-3133-9192

${ }^{1}$ Dunărea de Jos University, Galati, Romania,

${ }^{2}$ South Ural State University, Chelyabinsk, Russian Federation

\begin{abstract}
Aim. In the present paper we aim at highlighting the influence of motion games in improving the components of psychomotricity in the physical education lesson in primary school education (the preparatory school year) and in shaping, among pupils, the belief that the physical education activity is a personal necessity. Methods. During the 2018-2019 school year, within the physical education classes we implemented a program of 20 motion games, for the first semester, and 17 , for the second semester, meant to improve the psychomotor components. The research was carried out within the secondary school no. 1 Matca, Galati County, on a group of 50 preparatory school year pupils - the control group (24 subjects - 10 girls and 14 boys) and the experiment group ( 26 subjects - 13 girls and 13 boys), aged 6-7 years. For the evaluation of psychomotricity, we used the Bruininks-Oseretsky battery of tests, for segmental coordination and upper limb coordination, and the Motorin Test for general coordination. Results. In the final test, due to the implementation of motion games specific to the components of psychomotor activity, we noticed an ease of execution in the experiment group as compared to the control group, which still showed awkwardness and uncertainty in executing certain components of psychomotor activity by repeating the errors made in the initial test. Conclusions. After the creation and application of the training program in the school teaching activity, we reached the conclusion that it led to the acquisition of a high-level psychomotor components, and that it was qualitatively more valuable than the simple use of methods based on simple strength, sprint or endurance running, or dexterity exercises.
\end{abstract}

Keywords: segmental coordination, upper limb coordination, general coordination, physical education lesson.

\section{Introduction}

Psychomotricity is one of the forms of adaptation to the outside world that allows the preschool child to carry out both an exploration and an intellectual activity, involving himself/herself with his/her whole personality. Motricity, as a functional substructure of psychomotor activity, is the global name given to the muscular reactions through which the movement of the body or of its various components is performed. The quality of movements, and especially of gestures, is determined by the way in which information is received and interpreted, as well as by the quality of the response act, which is influenced not only by the motor factors, but also by the cognitive, emotional, motivational and volitional factors. It is a complex act, which combines the motor and the mental abilities in performing the action, and this act is called a psychomotor act. On the other hand, the concept of motricity expresses the ability of the human being to react with the help of the locomotor apparatus to internal and external stimuli, in the form of motion $[8,12]$.

The motor development of the child is the expression of several factors: somatic, functional, and psychological. As a result, a good level of motor skills of the child represents the mirror of the development stage reached and a success factor in his/her school activity. The motor approach can only be achieved in the context of the control that the psychological component has over it, control exercised by the means of the cognitive and motivational functions. In its turn, mental evolution is based on motion. The effects of neuromuscular maturation gradually lead the child from spontaneous motricity to an increasingly improved, more nuanced and differentiated motor activity $[9,10,14]$.

Since motor evolution is closely related to the mental one, the motor developments pave the way for intellectual advances. Within the motor development, the following aspects will be ana- 


\section{Спортивная тренировка}

lysed: general motricity and psychomotricity, through some of their components - fundamental motor skills, body representation, laterality, spatio-temporal orientation, considered to be essential elements for the adaptation to the school environment. In addition to these components, whose success conditions motor development, aspects related to a series of acquisitions specific to the maintenance of health, hygiene and personal safety were also analysed. Therefore, the assessment of physical and motor development addresses both some development landmarks and some acquisitions that 6-7 year-old children should have as a result of completing physical activities during kindergarten. Motricity represents the main source and means of expressing the child's mental acquisitions in the first years of life, a fact confirmed by the close connection between the motor and the nervous development, proven by numerous national and international studies on motion.

Following the study of the domain-specific literature and the research performed in the field in Romania, there is a lack of concern for researching and deepening the aspects regarding the importance of knowing the development level of psychomotricity in preparatory grade students $[1,5,7,11]$. Physical education is based on motion and it aims at improving the physical and mental condition of people, at harmoniously developing and maintaining health. It should also be emphasized that, carried out at the level of primary education, physical education also plays an important role in the shaping and the development of the child's personality. Specialists in the psycho-pedagogical field recognize the formative values of this school subject at the biological, motor, mental and social level. One of the basic factors of human and physical development is motion. Without motion, without the possibility to at least move, man would lead a static life. Motion is, therefore, part and parcel of human life itself. Thus, physical education, as an education of motion, has an undeniable importance, being a valuable asset of the developing man. The qualitative characteristic of physical education does not consist in the fact that a physical effort is made, but in the objectives pursued, in the way this activity is carried out and in the emphasis placed on the formative value of its content. Thus, the student participating in the physical education lesson reacts by a complex behaviour, which includes psychomotor development, motor skills, physical fitness, knowledge and pleasure for movement. The educational value of practising physical exercises depends decisively on how much the students enjoy the physical education class in school $[3,13]$.

Psychomotricity is viewed in the domainspecific literature as a complex function, an ability that integrates both aspects of motor activity and manifestations of perceptual functions. Psychomotricity gives the child the ability to use gestures, awareness of his/her body, places him/her in time and space, it ensures the ability to manage his/her movements in order to interact with himself/herself and the environment $[3,8,14]$.

The motor profile of the preschool child is reflected by the international context of research and the worldwide concerns in the field of early education, as well as the requirements and priorities at a national level $[6,9,10]$.

After reaching the age of 6 , the process of integration into school life begins in the child's life. In the first years of school, the pupil is highly responsive to everything that can be expressed through motion, as an objective need determined by the requirements of his/her development. By means of motion, the child improves certain acquired knowledge and it is important that motor activity be stimulated by creating different situations, using the method of activation on several planes. As a result of these activities, both the motor skills and the children's mental abilities are influenced. Another important element that helps in the formation of psychomotricity in small age school children is the development of curiosity and of cognitive inventiveness, this favouring the active involvement of children in carrying out the tasks. Games are the main training method for developing and strengthening motor skills. Games and competitions also become efficient means of solving other training topics and attaining objectives, after learning the rules of conduct and the specific motor tasks. Compared to other physical exercises, motion games have the advantage of involving a large number of students, both boys and girls, often in mixed groups, in a relatively small space. The present paper represents the equal contribution of its authors.

\section{Materials and Methods}

Subjects. The research was conducted during the 2018-2019 school year within the Secondary School no. 1 Matca, Galați County, on a sample of 50 subjects, from the preparatory grade the control group (24 subjects - 10 girls and 14 boys) and the experiment group (26 subjects 13 girls and 13 boys), over 6 years of age. 
Procedure. The main aim of the present paper is to highlight the influence of motion games in improving psychomotricity during the physical education class in primary school education (the preparatory grade) and in forming, among the pupils, the belief that the physical education class is a personal need, together with food, clothing, education, water, sun etc.

Another goal of the study is to create and implement a training program of motion games, which are based on improving the level of development of individual psychomotricity, in order to develop the components of psychomotricity in preparatory-grade students (20 games for the first semester and 17 games for the second semester) during physical education classes that focus on psychomotricity. The curriculum for the preparatory school year includes two classes per week, i.e. 90 minutes, for the physical education subject.

Taking into account the particularities of the children included in the preparatory grade, we used those methods that make the content of the physical education class attractive and accessible. Thus, the motion game becomes a method and means of organization, carried out in the form of a competition, adapted to the motor and mental abilities of the students.

Methods. As far as the methods used are concerned, we implemented the Bruininks Oseretsky battery of tests, in which we focused on the segment coordination items (7 items which measure the ability to coordinate movements that are performed simultaneously with both the upper and the lower limbs), on the upper limbs coordination (9 items by means of which arm motion coordination and hand and finger precision are highlighted) and on some aspects regarding the visual-motor coordination ( 7 items that measure static and dynamic balance) $[2,6]$.

For general coordination, we used The Matorin test [6].

Because at this age level there are no differences in the development level of the components that make up psychomotricity, the implementation of the evaluation tools were the same for both girls and boys, with no differences in interpreting the results of the final test.

\section{Results}

The curriculum for Physical Education for the preparatory school year, 1st and 2nd grades [4] is developed according to a competencecentred model of curricular design. The design of the curriculum is achieved in such a way as to contribute to the development of the students in primary school education. From the perspective of PE, the competence-centred teaching approach allows the accomplishment of the purpose and it emphasizes the action-based component in shaping the student's personality.

The inclusion of the preparatory school year in general and compulsory education implies a nuanced perspective of the curriculum at this age level. There is a need for a specific approach to early education, based essentially on stimulating learning through play, which at the same time offers a wide range of differentiation of the teaching approach, depending on the level of various student acquisitions.

Certain motor skills are formed by means of day-to-day activities, others are acquired in a specially organized environment, i.e. in the physical education class. In this educational process, some motor skills, which are wrongly learned in the practice of life, can be corrected and some skills acquired during this period are consolidated or perfected.

During the preschool period the motor activity begins to be differentiated from the intellectual one, the motor act gradually comes under the domination of the mental component. During the early school period, the motor level begins to change, it becomes automated and different from the intellectual one. The core of the psychomotor phenomenon is made up of the children's desire to move around, which is the main factor which stimulates mental evolution and organic processes. The motor development of the 6-7 yearold child is in the stage of fundamental movement maturation, stage in which the locomotor skills (walking, running, jumping, climbing, getting past obstacles, etc.), the handling skills (throwing, catching, hitting, flipping, volleying, bouncing, rolling) and the balance skills (twists, turns, maintaining balance, rolling, etc.) are formed and strengthened. This stage can be reached for most movements around the age of 6 years. Children reach this stage at a different pace. Some may fall behind or fail to acquire certain skills, while others may reach this stage faster. The age period beginning at $6 / 7$ years is a period of intense motor development, which can be illustrated both by the evolution of the components of psychomotricity and by the motor skills, which create important prerequisites for the formation of fundamental motor and sports skills.

For the evaluation of specific components of psychomotricity we applied the Bruininks Oseretsky - test (initial and final testing) to the two 


\section{Спортивная тренировка}

research groups and the results of the evaluation are presented in the following tables.

The analysis and interpretation of the resultsrelied on the statistical calculation carried is presented in tables 2 and 3 below.

Comparing the percentages obtained by the two groups at the final test in tables 1 and 2, we may notice that the experiment group recorded percentages of over $80 \%$ and decreased the negative score percentages for all 7 items, as compared to the control group that obtained over $70 \%$ only in 5 of the 7 items, fact which shows the efficiency of the game program implementation for improving the psychomotor components of the experiment group.

Item 2, which consisted of making synchronized beats with the same side leg and index finger created problems for the students. In the initial testing, the experiment group didn't perform well, because many subjects tended to beat at the same time with their index fingers and toes, and they could not perform the actions at a time. In the control group the girls showed better coordination. In the final test, however, predominantly the girls from the experiment group man- aged to make a much better difference between simultaneous and alternative actions.

Item 6 involved performing a standing high jump with a clap over the head. In the final test, the experiment group had better results, the subjects had better coordination than those in the control group, who failed to coordinate their arms and legs, their hands were below the chest level or they performed the clap either before jumping or after landing.

Within item 7, the deficit of segmental coordination development was more severe and consisted of executing a vertical jump and touching the heels with the hands. In the initial test, both groups encountered problems and made the same mistakes: they did not touch the heels with their hands simultaneously, they only jumped with one leg instead of jumping with both legs at the same time, they were unable to maintain balance and they touched the floor with one or both hands. In the final test, the experiment group managed to have the best results, had better mobility and made fewer mistakes than the control group.

In the evaluation of the upper limbs coordination, the most problematic items were:

The scores obtained when evaluating the segmental coordination within the control group $(n=24)$

\begin{tabular}{|c|c|c|c|c|c|c|c|c|}
\hline & \multirow{2}{*}{ Points } & \multicolumn{7}{|c|}{ Items } \\
\hline & & 1 & 2 & 3 & 4 & 5 & 6 & 7 \\
\hline \multirow{5}{*}{ : } & 0 & $58.33 \%$ & $20.83 \%$ & $25 \%$ & $33.33 \%$ & $16.66 \%$ & - & $54.16 \%$ \\
\hline & 1 & $41.66 \%$ & $79.16 \%$ & $75 \%$ & $66.66 \%$ & $83.33 \%$ & $4.16 \%$ & $45.83 \%$ \\
\hline & 2 & - & - & - & - & - & $20.83 \%$ & - \\
\hline & 3 & - & & - & - & - & $41.66 \%$ & - \\
\hline & 4 & - & - & - & - & - & $33.33 \%$ & - \\
\hline \multirow{5}{*}{ 点 } & 0 & $29.16 \%$ & $20.83 \%$ & $25 \%$ & $25 \%$ & $29.16 \%$ & - & $33.33 \%$ \\
\hline & 1 & $70.83 \%$ & $79.16 \%$ & $75 \%$ & $75 \%$ & $70.83 \%$ & $4.16 \%$ & $66.66 \%$ \\
\hline & 2 & - & - & - & - & - & $12.5 \%$ & - \\
\hline & 3 & - & - & - & - & - & $33.33 \%$ & - \\
\hline & 4 & - & - & - & - & - & $50 \%$ & - \\
\hline
\end{tabular}

Table 2

The scores obtained when evaluating segmental coordination within the experiment group $(n=26)$

\begin{tabular}{|c|c|c|c|c|c|c|c|c|}
\hline & \multicolumn{8}{|c|}{ Items } \\
\hline & Points & 1 & 2 & 3 & 4 & 5 & 6 & 7 \\
\hline \multirow{5}{*}{$\stackrel{\text { : }}{\stackrel{\Xi}{\Xi}}$} & 0 & $53.84 \%$ & $46.15 \%$ & $53.84 \%$ & 34.61 & $23.07 \%$ & - & $65.38 \%$ \\
\hline & 1 & $46.15 \%$ & $53.84 \%$ & $46.15 \%$ & $65.38 \%$ & $76.92 \%$ & - & $34.61 \%$ \\
\hline & 2 & - & - & - & - & - & $15.38 \%$ & - \\
\hline & 3 & - & - & - & - & - & $26.92 \%$ & - \\
\hline & 4 & - & - & - & - & - & $53.84 \%$ & - \\
\hline \multirow{4}{*}{ 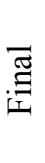 } & 0 & $11.53 \%$ & $15.38 \%$ & $11.53 \%$ & $15.38 \%$ & $11.53 \%$ & - & $19.23 \%$ \\
\hline & 1 & $88.46 \%$ & $84.61 \%$ & $88.46 \%$ & $84.61 \%$ & $88.46 \%$ & - & $80.76 \%$ \\
\hline & 3 & - & - & - & - & - & $11.53 \%$ & - \\
\hline & 4 & - & - & - & - & - & $88.46 \%$ & - \\
\hline
\end{tabular}


Item 3 - catching the ball thrown by the examiner with both hands - in the initial test most subjects made the same mistakes: they did not correctly estimate the distance between them and the ball, so most of the time they failed to catch the ball with both hands in the right position, in front of the chest, but they caught it near the abdomen, hip or it hit their head. Some subjects from the control group failed to catch the ball at all, dropping it outside the demarcated area. In the final test we noticed that the experiment group was better at carrying out the task given, they were more careful and they managed to catch the ball without repeating the mistakes from the initial test.

Item 4 - catching the ball thrown by the examiner with the preferred hand - was a difficult task to perform for both groups in the initial test, some subjects failed to catch the ball with their preferred hand completely, and many others dropped the ball outside the demarcated area. In the final test, some subjects in both groups encountered the same problems as in the initial test, but the experiment group was able to obtain better results than the control group because they showed more dexterity.
Item 5 - throwing the ball to a target with the preferred hand - in the initial test neither group had very good results, because most of the subjects made the same mistakes: they did not hit the target (they threw the ball either above or below the target), they threw it from below and not holding the hand near the shoulder or they stepped over the line of the demarcated area. In the final test, the experiment group managed to obtain a higher percentage of correct throws as compared to the control group and its members had better precision.

Comparing the percentages from Tables 3 and 4 we may note that the experiment group recorded progress of more than $50 \%$ and reduced the low score percentage for all 9 items, as compared to the control group that obtained over $50 \%$ only in 5 of the 9 items, fact which demonstrates the efficiency of the game program implementation for improving the psychomotor components of the experiment group.

The major categories regarding balance are the static and dynamic balance. Static balance refers to the ability to maintain a stationary position, while dynamic balance represents the ability to maintain balance during movement, this aspect

The scores obtained when evaluating the upper limbs coordination within the control group

Table 3

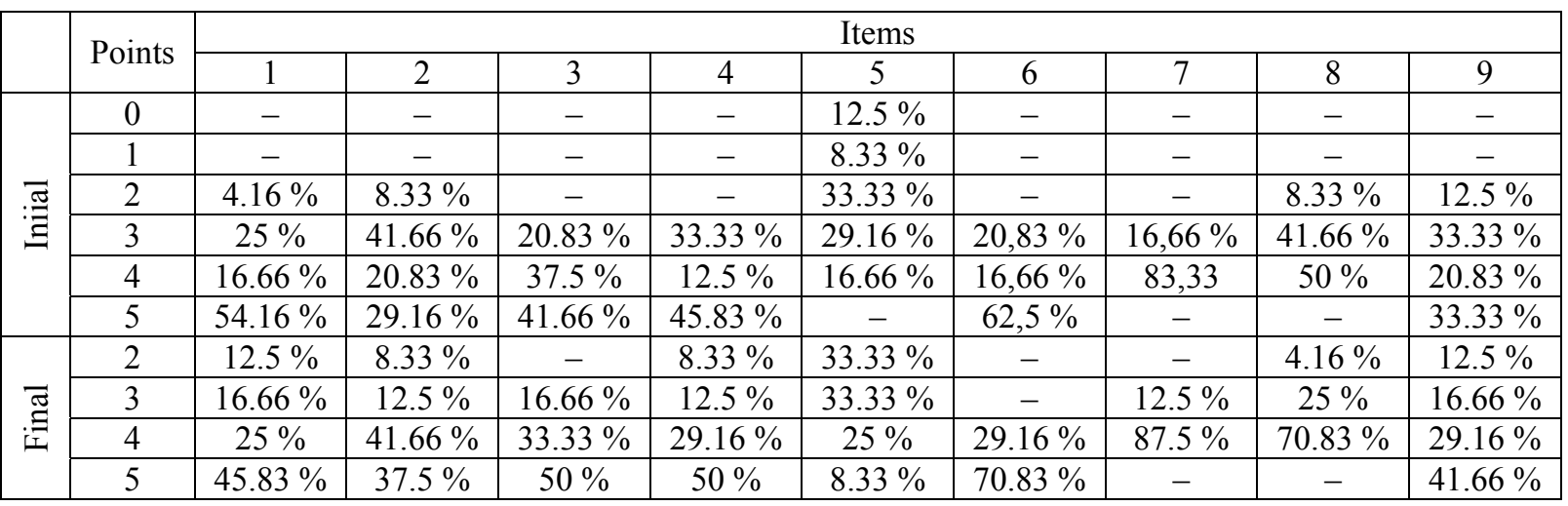

The scores obtained in the evaluation of the upper limbs coordination within the experiment group

Table 4

\begin{tabular}{|c|c|c|c|c|c|c|c|c|c|c|}
\hline & \multirow{2}{*}{ Points } & \multicolumn{9}{|c|}{ Items } \\
\hline & & 1 & 2 & 3 & 4 & 5 & 6 & 7 & 8 & 9 \\
\hline \multirow{5}{*}{ : } & 1 & - & - & - & - & $19.23 \%$ & - & - & $3.84 \%$ & - \\
\hline & 2 & $15.38 \%$ & $3.84 \%$ & & $15.38 \%$ & $34.61 \%$ & $23.07 \%$ & - & $7.69 \%$ & $15.38 \%$ \\
\hline & 3 & $34.61 \%$ & $34.61 \%$ & $19.23 \%$ & $34.61 \%$ & $30.76 \%$ & $46.15 \%$ & $11.53 \%$ & $11.53 \%$ & $7.69 \%$ \\
\hline & 4 & $7.69 \%$ & $26.92 \%$ & $30.76 \%$ & $19.23 \%$ & $11.53 \%$ & $19.23 \%$ & $88.46 \%$ & $76.92 \%$ & $11.53 \%$ \\
\hline & 5 & $42.30 \%$ & $34.61 \%$ & $46.15 \%$ & $30.76 \%$ & $3.84 \%$ & $11.53 \%$ & - & - & $65.38 \%$ \\
\hline \multirow{4}{*}{ 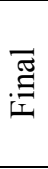 } & 2 & - & - & - & - & $7.69 \%$ & $3.84 \%$ & - & - & - \\
\hline & 3 & $7.69 \%$ & $19.23 \%$ & $15.38 \%$ & $30.76 \%$ & $26.92 \%$ & $7.69 \%$ & $7.69 \%$ & $11.53 \%$ & $15.38 \%$ \\
\hline & 4 & $26.92 \%$ & $15.38 \%$ & $3.84 \%$ & $15.38 \%$ & $34.61 \%$ & $15.38 \%$ & $92.30 \%$ & $88.46 \%$ & $7.69 \%$ \\
\hline & 5 & $65.38 \%$ & $65.38 \%$ & $80.76 \%$ & $53.84 \%$ & $30.76 \%$ & $73.07 \%$ & - & - & $76.92 \%$ \\
\hline
\end{tabular}




\section{Спортивная тренировка}

being highlighted in the 8 items of the Bruininks Oseretsky test battery for static and dynamic balance.

Item 3 - standing on one leg on the balance beam with the eyes closed - in the initial test, we noticed that the subjects in both groups failed to maintain their balance for a long time, they swung a lot on the leg they had on the ground or put on the ground the foot they held in the air, or they opened their eyes. In the final test, we noticed that the static balance level improved significantly in the experiment group, they did not swing so much on the support leg and there were a larger number of subjects who were able to maintain their balance in a static position for 10 seconds.

Item 7 - stepping forward, heel to toe, on the balance beam - most subjects in the two groups made most of the same mistakes in the initial test: they did not touch the heel from the front foot with the toes of the back foot, fell from the balance beam or swung their arms a lot. In the final test, progress was made both by the control and the experiment groups, but especially by the experiment group.

Item 8 - walking over an obstacle on the balance beam - in the initial test, most of the subjects in the control group and almost half of those in the experiment group, touched the obstacle during walking, stretched the foot around the end of the obstacle or didn't step on the beam. In the final test we noticed a better level of dynamic balance and a faster movement speed in the experiment group as compared to the control group.

From tables 5 and 6 we may see that, as far as the static and dynamic balance are concerned, in the experiment group there was a much higher increase in the average of the results regarding the 8 items as compared to the control group.

General coordination (the Matorin test). The level of overall coordination of the subjects in the two groups in the initial test was quite

The results of the static and dynamic balance evaluation within the control group

Table 5

\begin{tabular}{|c|c|c|c|c|c|c|c|c|}
\hline & \multicolumn{8}{|c|}{ Items } \\
\hline & 1 & 2 & 3 & 4 & 5 & 6 & 7 & 8 \\
\hline & $\begin{array}{l}10 "-50 \% \\
9 "-16.66 \% \\
8 "-16.66 \% \\
6 "-12.5 \% \\
3 "-4.16 \%\end{array}$ & $\begin{array}{l}10 "-50 \% \\
9 "-16.66 \% \\
8 "-12.5 \% \\
7 "-16.66 \%\end{array}$ & $\begin{array}{l}10 "-20.83 \% \\
9 "-33.33 \% \\
8 "-25 \% \\
7 "-4.16 \% \\
6 "-12.5 \% \\
4 "-4.16 \%\end{array}$ & \begin{tabular}{|l}
$6-37.5 \%$ \\
$5-37.5 \%$ \\
$4-16.66 \%$ \\
$3-8.33 \%$
\end{tabular} & $\mid \begin{array}{l}6-20.83 \\
5-33.33 \% \\
4-29.16 \% \\
3-16.66 \%\end{array}$ & $\mid \begin{array}{l}6-16.66 \% \\
5-41.66 \% \\
4-29.16 \% \\
3-8.33 \%\end{array}$ & $\left|\begin{array}{l}6-16.66 \% \\
5-29.16 \% \\
4-37.5 \% \\
3-16.66 \%\end{array}\right|$ & $\begin{array}{l}1-50 \% \\
0-50 \%\end{array}$ \\
\hline 矛 & $\begin{array}{l}10 "-41.66 \% \\
9 "-41.66 \% \\
8 "-4.16 \% \\
7 "=-4.16 \% \\
6 "-8.33 \%\end{array}$ & $\begin{array}{l}10 "-58.33 \% \\
9 "-25 \% \\
8 "-4.16 \% \\
6 "-12.5 \%\end{array}$ & $\begin{array}{l}10 "-41.66 \% \\
9 "-33.33 \% \\
8 "-4.16 \% \\
7 "-8.33 \% \\
6 "-12.5 \%\end{array}$ & \begin{tabular}{|l}
$6-50 \%$ \\
$5-29.16 \%$ \\
$4-12.5 \%$ \\
$3-8.33 \%$
\end{tabular} & $\begin{array}{l}6-37.5 \% \\
5-29.16 \% \\
4-25 \% \\
3-8.33 \%\end{array}$ & $\begin{array}{l}6-45.83 \% \\
5-33.33 \% \\
4-16.66 \% \\
3-4.16 \%\end{array}$ & $\begin{array}{l}6-41.66 \% \\
5-25 \% \\
4-25 \% \\
3-4.16 \%\end{array}$ & $\begin{array}{l}1-66.66 \% \\
0-33.33 \%\end{array}$ \\
\hline
\end{tabular}

Here and in the table $6 "$ - seconds; T - tests.

The results of the static and dynamic balance evaluation within the experiment group

\begin{tabular}{|c|c|c|c|c|c|c|c|c|}
\hline & \multicolumn{8}{|c|}{ Items } \\
\hline & 1 & 2 & 3 & 4 & 5 & 6 & 7 & 8 \\
\hline$: \stackrel{\Xi \Xi}{\Xi}$ & $\begin{array}{l}10 "-38.46 \% \\
9 "-26.92 \% \\
8 "-19.23 \% \\
7 "-7.69 \% \\
6 "-3.84 \% \\
3 "-3.84 \% \\
\end{array}$ & $\begin{array}{l}10 "-50 \% \\
9 "-19.23 \% \\
8 "-7,69 \% \\
7 "-11.53 \% \\
6 "-11.53 \%\end{array}$ & $\begin{array}{l}10 "-26.92 \% \\
9 "-7.69 \% \\
8 "-26.92 \% \\
7 "-26.92 \% \\
6 "-7.69 \% \\
4 "-3.84 \% \\
\end{array}$ & $\begin{array}{l}6-38.46 \% \\
5-26.92 \% \\
4-30.76 \% \\
3-3.84 \%\end{array}$ & $\begin{array}{l}6-26.92 \% \\
5-19.23 \% \\
4-30.76 \% \\
3-23.07 \%\end{array}$ & $\begin{array}{l}6-30.76 \% \\
5-34.61 \% \\
4-30,76 \% \\
3-3.84 \%\end{array}$ & $\left|\begin{array}{l}6-7.69 \% \\
5-19.23 \% \\
4-38.46 \% \\
3-34.61 \%\end{array}\right|$ & $\begin{array}{l}1-57.69 \% \\
0-42.30 \%\end{array}$ \\
\hline 胥 & $\mid \begin{array}{l}10 "-88.46 \% \\
9 "-3.84 \% \\
8 "-3.84 \% \\
7 "-3.84 \%\end{array}$ & $\begin{array}{l}10 "- \\
69.23 \% \\
9 "-23.07 \% \\
8 "-3.84 \% \\
7 "-3.84 \%\end{array}$ & $\begin{array}{l}10 "-57.69 \% \\
9 "-30.76 \% \\
8 "-7.69 \% \\
7 "-3.84 \%\end{array}$ & $\begin{array}{l}6-73.07 \% \\
5-23.07 \% \\
4-3.84 \%\end{array}$ & $\begin{array}{l}6-65.38 \% \\
5-26.92 \% \\
4-7.69 \%\end{array}$ & $\begin{array}{l}6-65.38 \% \\
5-23.07 \% \\
4-11.53 \%\end{array}$ & 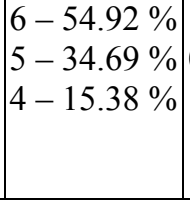 & $\begin{array}{l}1-92.30 \% \\
0-7.69 \%\end{array}$ \\
\hline
\end{tabular}


good compared to the low level we were initially expecting. However, some subjects from both groups couldn't maintain their balance when turning 360 degrees. In the final test, the experiment group recorded a higher degree of general coordination and a better balance when turning 360 degrees.

Table 7

\begin{tabular}{|c|c|c|}
\hline \multirow{2}{*}{ Samples } & Initial test & Final test \\
\hline & $\mathrm{X} \pm \sigma$ & $\mathrm{X} \pm \sigma$ \\
\hline ntrol group & $272.91 \pm 59.88$ & $285.41 \pm 50.73$ \\
\hline $\begin{array}{l}\text { periment } \\
\text { up }\end{array}$ & $266.53 \pm 56.63$ & $312.69 \pm 46.09$ \\
\hline
\end{tabular}

In the case of the control group, the difference of the averages has a value of 12.5 degrees, whereas in the experiment group, the difference of the averages has a value of 46.16 degrees.

The difference of the two groups' final averages is 27.28 degrees in favour of the experiment group. Table 7 shows that the experiment group recorded much higher percentages in the final test than the control group.

\section{Conclusion}

For small-age school children, we managed to prove the applicability of physical exercise games in motor and dynamic movement activities and the pleasure they create for the participants. The following conclusions were drawn:

- By analysing the first results (in the initial tests), we saw a negative influence on the motor age of small - age school children from the part of modern civilization (standard of living, technology, automation, sedentary way of life, replacement of outdoor games with video games). That is why we recommend an intervention strategy in the educational process, using curricula based on specific topics, in order to favour the education of pupils' psychomotor components in primary education.

- In the final test, due to the implementation of motion games specific to the components of psychomotor activity, we noticed an ease of execution in the experiment group as compared to the control group, which still showed awkwardness and uncertainty in executing certain components of psychomotor activity by repeating the errors made in the initial test.

- In the final test, in both groups, the girls obtained better results than the boys.
The basic conclusion is that the creation and implementation of the training program in the school teaching activity led to the acquisition of a high level of the obvious and qualitatively more valuable psychomotor components than the simple use of methods based on simple strength, sprint or endurance running, or dexterity exercises.

\section{References}

1. Albu C., Albu A., Vlad T., Iacob I. Psihomotricitatea. Iasi: Institutul European, 2006, pp. 35-37.

2. Bruininks R.H. Examiner's Manual: Bruininks-Oseretsky Test of Motor Proficiency. Minnesota. American Guidance Service, 1978, pp. 17-19.

3. Camargos E.K., Maciel R.M. The Importance of Psychomotricity in Children Education. Multidisciplinary Core scientificjournal of knowledge, 2016, vol. 9, pp. 254-275.

4. Curriculum for Physical Education, Ministerial Order no. 3418/2013.

5. Gavritiu (Nitulescu) I.C., Hora A.V., Matei C.B. Creativity in Teaching Psychomotricity During Early Childhood Education, Discobolul Physical Education, Sport and Kinetotherapy Journal, 2017, vol. 4 (50), pp. 73-75.

6. Horghidan V. Metode de Psihodiagnostic, Ed. Didacticăşi Pedagogică R.A. Bucureşti, 1997, pp. 153-164.

7. Horghidan V. Problematica Psihomotricităţii. Bucuresti, Globus, 2000, pp. 79-83.

8. Jongmans M.J., Linthorst-Bakker E., Westenberg Y., Smits-Engelsman B.C.M. Use of a Task-Oriented Self-Instruction Method to Support Children in Primary School with Poor Hand Writing Quality and Speed. Human Movement Science, 2003, vol. 22, pp. 549-566. DOI: 10.1016/j.humov.2003.09.009

9. Jorge Manuel Gomes de AzevedoF., Filho G., Barbosa P.J., Alexandre Luiz Gonçalves de R. Psicomotricidade, Jogo e Corpo-em-relação: Contribuições para a Intervenção. Cad. Bras. Ter. Ocup., 2018, vol. 26 (3), pp. 702-709. DOI: 10.4322/2526-8910.ctoEN1232

10. Kolumbet A. Methodic of Girlstudents' Professionally Significant Coordination Qualities' Perfection at Physical Education Classes. Physicaleducation of students, 2016, vol. 20 (4), pp. 35-43. DOI: $10.15561 / 20755279.2016 .0404$

11. Lazăr G. Improving the Balance in Children of 6-7 Years in Physical Education Les- 


\title{
Спортивная тренировка
}

son through Music Movement Games. The Annals of the "Stefan Cel Mare" University, 2018, vol. 11 (2), pp. 60-69.

12. Le Boulch J. Le Développement Psychomoteur de la Naissance à 6 ans. Conséquences Éducatives. La Psychocinétique à L'âgepré Scolaire. Les Editions E.S.F. Paris, 1981, pp. 46-52.

13. Mas M., Jiménez L., Riera C. Systema- tization of the Psychomotor Activity and Cognitive Development. Psicología Educativa, 2018, vol. 24, pp. 38-41. DOI: 10.5093/psed2018a5

14. Pons R., Arufe V. Análisis Descriptivo de Las Sesiones e Instalaciones de Psicomotricidaden el aula de EducaciónInfantil. Sportis Scientific Technical Journal, 2015, vol. 2 (1), pp. 125-146. DOI: $10.17979 /$ sportis.2016.2.1.1445

Received 25 November 2019

\section{ВЛИЯНИЕ ПОДВИЖНЫХ ИГР НА УРОКАХ ФИЗИЧЕСКОЙ КУЛЬТУРЫ В НАЧАЛЬНОЙ ШКОЛЕ НА УЛУЧШЕНИЕ ПСИХОМОТОРИКИ}

\author{
Т.М. Икономеску', А. Бердила' ${ }^{1}$ Л.Г. Талагир ${ }^{1,2}$ \\ ${ }^{1}$ Университет «Нижний Дунай», г. Галац, Румыния, \\ ${ }^{2} Ю$ жно-Уральский государственный университет, г. Челябинск, Россия
}

Цель. Цель настоящего исследования - изучить влияние подвижных игр на уроках физической культуры в начальной школе (подготовительный год) на компоненты психомоторики и формирование представлений о физической культуре как о личной необходимости учеников. Материалы и методы. В 2018-2019 академическом году на уроках физической культуры была представлена программа, состоящая из 20 (первый семестр) и 17 (второй семестр) подвижных игр, направленных на улучшение психомоторики. Исследование проводилось в общеобразовательной школе № 1 (коммуна Матча, округ Галац) с участием 50 учеников подготовительных классов в возрасте 6-7 лет: контрольная (24 участника - 10 девочек и 14 мальчиков) и экспериментальная (26 участников - 13 девочек и 13 мальчиков) группа. Для оценки психомоторики были использованы тесты Бруининкса - Озерецкого (сегментарная координация и координация верхних конечностей), а также тест Моторина для оценки общей координации. Результаты. По результатам итогового тестирования была отмечена легкость, с которой участники экспериментальной группы выполняли упражнения относительно контрольной группы. В контрольной группе по-прежнему отмечались затруднения и неловкость, связанные с выполнением отдельных заданий, что проявлялось в повторении ошибок, совершенных во время исходного тестирования. Заключение. После создания и применения тренировочной программы был сделан вывод о ее пользе для повышения уровня психомоторных навыков, а также о качественно более высокой ценности данной программы в сравнении с такими упражнениями, как спринт, бег на выносливость, силовыми упражнениями или упражнениями на ловкость.

Ключевые слова: сегментарная координация, координация верхних конечностей, общая координация, уроки физической культуры. 
Теодора Михаэла Икономеску, доцент, $\mathrm{PhD}$, Университет «Нижний Дунай», факультет физического воспитания и спорта. Ул. Домняскэ, 47, 800008, г. Галац, Румыния. E-mail: ticonomescu@ugal.ro, ORCID: 0000-0001-5780-4403.

Анамария Бердила, аспирант, Университет «Нижний Дунай», факультет физического воспитания и спорта. Ул. Домняскэ, 47, 800008, г. Галац, Румыния. E-mail: annie.volley@yahoo.com, ORCID: 0000-0003-2032-2667.

Лауренциу-Габриэль Талагир, $\mathrm{PhD}$, профессор, Университет «Нижний Дунай», факультет физического воспитания и спорта. Ул. Домняскэ, 47, 800008, г. Галац, Румыния; ЮжноУральский государственный университет. 454080, г. Челябинск, проспект Ленина, 76. E-mail: gtalaghir@ugal.ro, ORCID: 0000-0002-3133-9192.

Поступила в редакцию 25 ноября 2019 г.

\section{ОБРАЗЕЦ ЦИТИРОВАНИЯ}

Iconomescu, T.M. The Influence of Motion Games in the Improvement of Psychomotricity During the Physical Education Lesson in Primary School Education / T.M. Iconomescu, A. Berdilă, L.G. Talaghir // Человек. Спорт. Медицина. - 2019. - Т. 19, № S2. - С. 65-73. DOI: $10.14529 / \mathrm{hsm} 19 \mathrm{~s} 209$

\section{FOR CITATION}

Iconomescu T.M., Berdilă A., Talaghir L.G. The Influence of Motion Games in the Improvement of Psychomotricity During the Physical Education Lesson in Primary School Education. Human. Sport. Medicine, 2019, vol. 19, no. S2, pp. 65-73. DOI: 10.14529/hsm19s209 